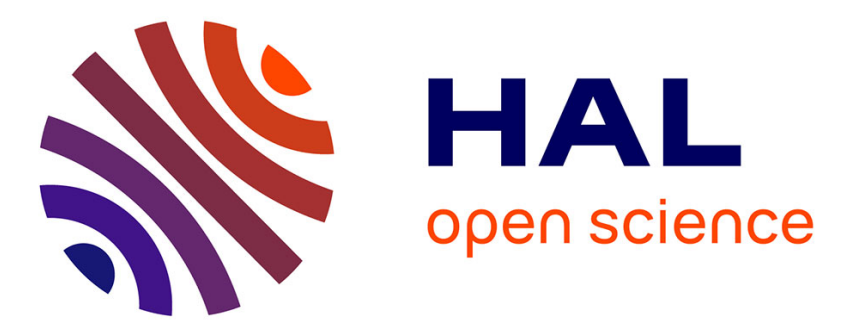

\title{
Absence of oxygen affects the capacity to sporulate and the spore properties of Bacillus cereus
}

Amina Aicha Abbas, Stella Tichit-Planchon, Michel Jobin, Philippe Schmitt

\section{To cite this version:}

Amina Aicha Abbas, Stella Tichit-Planchon, Michel Jobin, Philippe Schmitt. Absence of oxygen affects the capacity to sporulate and the spore properties of Bacillus cereus. Food Microbiology, 2014, 42, pp.122-131. 10.1016/j.fm.2014.03.004 . hal-02641610

\section{HAL Id: hal-02641610 \\ https://hal.inrae.fr/hal-02641610}

Submitted on 28 May 2020

HAL is a multi-disciplinary open access archive for the deposit and dissemination of scientific research documents, whether they are published or not. The documents may come from teaching and research institutions in France or abroad, or from public or private research centers.
L'archive ouverte pluridisciplinaire HAL, est destinée au dépôt et à la diffusion de documents scientifiques de niveau recherche, publiés ou non, émanant des établissements d'enseignement et de recherche français ou étrangers, des laboratoires publics ou privés. 
Version définitive du manuscrit publiée dans / Final version of the manuscript published in :

Food Microbiology (2014), Vol. 42, p. 122-131, DOI: 10.1016/j.fm.2014.03.004

Journal homepage: http://www.elsevier.com/locate/fm

\title{
Absence of oxygen affects the capacity to sporulate and the spore properties of Bacillus cereus
}

\author{
Amina Aicha Abbas ${ }^{\mathrm{a}, \mathrm{b}}$, Stella Planchon ${ }^{\mathrm{a}, \mathrm{b}, 1}$, Michel Jobin ${ }^{\mathrm{a}, \mathrm{b}}$, Philippe Schmitt ${ }^{\mathrm{a}, \mathrm{b}, *}$ \\ a INRA, UMR408 Sécurité et Qualité des Produits d'Origine Végétale, F-84000 Avignon, France \\ ${ }^{\mathrm{b}}$ Université d'Avignon et des Pays de Vaucluse, UMR408 Sécurité et Qualité des Produits d'Origine Végétale, F-84000 Avignon, France
}

Keywords:

B. cereus

Anaerobiosis

Sporulation

Strain diversity

Resistance

Germination

\begin{abstract}
A B S T R A C T
This study was performed to evaluate the effect of anaerobiosis on the formation of Bacillus cereus spores and their resulting properties. For this purpose, an appropriate sporulation medium was developed (MODs). Sporulation of 18 strains from different phylogenetic groups of $B$. cereus was studied in MODs medium in aerobiosis and anaerobiosis. In anaerobiosis, sporulation ability was weaker and more heterogeneous than in aerobiosis. Among tested strains, B. cereus AH187 produced the highest level of spores in anaerobiosis. This strain was therefore chosen to study spore properties. Spores produced in anaerobiosis were more resistant to wet heat at $90{ }^{\circ} \mathrm{C}, 92.5^{\circ} \mathrm{C}, 95^{\circ} \mathrm{C}, 97.5^{\circ} \mathrm{C}$ and $100{ }^{\circ} \mathrm{C}$. For example, $D_{90}$ were $21,09 \pm 1.70$ and $81.87 \pm 2.00$ for aerobiosis and anaerobiosis conditions, respectively. Spores produced in anaerobiosis have a $z$-value of $7.70{ }^{\circ} \mathrm{C}$ compared with $10.52{ }^{\circ} \mathrm{C}$ for spores produced in aerobiosis. Spores produced in anaerobiosis were also more resistant to $1 \mathrm{M} \mathrm{NaOH}, 1 \mathrm{M}$ nitrous acid and pulsed light at fluences of $0.34 \mathrm{~J} \mathrm{~cm}^{-2}$ and $0.49 \mathrm{~J} \mathrm{~cm}^{-2}$. No difference in resistance to UV-C, $5 \%$ hydrogen peroxide or $0.25 \mathrm{mM}$ formaldehyde was observed between these two conditions. In the presence of L-alanine, spores produced in anaerobiosis germinated more efficiently than spore produced in aerobiosis. No difference in germination was observed with inosine as inducer. No difference in the size of spores produced in the different conditions was observed by transmission electron microscopy. However, spores obtained under anaerobic conditions had a damaged exosporium, or in some cases a completely detached exosporium, unlike spores produced under aerobic conditions.

This study shows that few spores are formed under anaerobic condition; nevertheless, this condition has an impact on the spore properties of B. cereus AH 187 strain. Spores obtained under anaerobic condition were more resistant to heat and to some chemical compounds. This is an important feature, considering the risk associated with the presence of this pathogen in thermally processed and packaged

food in absence of oxygen.
\end{abstract}

\section{Introduction}

The Bacillus cereus group is formed of ubiquitous Gram-positive facultative anaerobic endospore-forming bacteria. It comprises seven phylogenetically close species: Bacillus thuringiensis, Bacillus anthracis, Bacillus mycoides, Bacillus pseudomycoides, Bacillus weihenstephanensis, Bacillus cytotoxicus and B. cereus sensu stricto. Seven major phylogenetic groups (I-VII) have been identified, with ecological differences that are evidence for a multiemergence of

\footnotetext{
* Corresponding author. INRA, UMR408, Site Agroparc, 84914 Avignon Cedex 9 , France. Tel.: +33 (0) 432722545

E-mail address: philippe.schmitt@univ-avignon.fr (P. Schmitt).

1 Present address: CTCPA - UMT Qualiveg. Site Agroparc, 449 avenue Clément Ader, ZA de l'Aéroport - BP21203, 84911 Avignon Cedex 9, France.
}

psychrotolerance in the B. cereus group. A moderate thermotolerant group (VII) was basal to the mesophilic group I, from which in turn distinct thermal lineages have emerged, comprising two mesophilic groups (III, IV), an intermediate group (V) and two psychrotolerant groups (II, VI) (Guinebretiere et al., 2008, 2013). B. cereus is frequently isolated from foods and it can cause two types of foodborne disease, described as emetic and diarrheal. The emetic syndrome results from toxins produced in the ingested food. Diarrheal toxi-infection results from ingesting food contaminated by $B$. cereus, whose cells transit through the digestive tract and produce the diarrheal toxins in the small intestine (Perez Portuondo, 2012; Ceuppens et al., 2013).

Under environmental stress conditions such as nutrient deprivation, $B$. cereus cells are able to produce spores (Moir et al., 2002; Setlow, 2003; Setlow and Johnson, 2007). Sporulation can take 
Version définitive du manuscrit publiée dans / Final version of the manuscript published in :

Food Microbiology (2014), Vol. 42, p. 122-131, DOI: 10.1016/j.fm.2014.03.004

Journal homepage: http://www.elsevier.com/locate/fm

place (i) in soil (considered the natural habitat of spores), (ii) insects, and animal gut, and (iii) food processing lines or food such as ready-to-eat foods, dairy products and vegetables. It is well known that spores are able to resist chemical and physical stresses such as air-drying, high temperature, high pressure, UV light and acidity (Clavel et al., 2004; Setlow, 2006; Tam et al., 2006; Nguyen Thi Minh et al., 2011). This high resistance ability is in some extent due to the presence of calcium dipicolinate and the dehydration state of the spore core (de Vries et al., 2005). These properties favor their survival through food processing and their long-term persistence in foods, where they cause serious problems (Andersson et al., 1995; Carlin, 2011). Under suitable conditions, B. cereus spores are able to germinate and revert to life as vegetative cells responsible for toxins production (Paredes-Sabja et al., 2011). Germination may take place within minutes; this depends on strains and conditions under which spores have been produced. In addition, germination can be initiated by some amino acids, sugars or other compounds found in complex culture media in bacilli (van der Voort et al., 2010; McKenney et al., 2013).

The different environments where sporulation take place present numerous temperatures and nutrient conditions affecting various spore properties, including resistance to many different stress factors, structure and composition (Margulis et al., 1998; Nicholson, 2002; Cazemier et al., 2001; Melly et al., 2002; Rose et al., 2007; Nguyen Thi Minh et al., 2008; van der Voort et al., 2010; van der Voort and Abee, 2013). In B. cereus and Bacillus subtilis, the effect of temperature and nutrient conditions on spore resistance to heat, UV and chemicals and germination has been extensively studied (Melly et al., 2002; Faille et al., 2007; GouninaAllouane et al., 2008; Planchon et al., 2011). Few studies on the effect of anaerobiosis on sporulation of the $B$. cereus group have been published except the effect of oxygen on the sporulation capacity of $B$. thuringiensis but spore properties were not studied (Avignone-Rossa et al., 1992; Finlay et al., 2002; Boniolo et al., 2012). Most studies on sporulation in anaerobic condition were performed with the anaerobic clostridia species (Paredes et al., 2005). However, B. cereus vegetative cells can be found in a large variety of natural environments with low oxygen level (intestine, soil or on food processing line) where sporulation can take place. Then, spores of $B$. cereus can be found in various food processing intermediates and foods products. Spores produced in these anaerobic environments could have particular properties and cause a problem of food safety.

The aim of this work was to investigate the sporulation capacity of $B$. cereus in an anaerobiosis environment. In this work, a panel of strains belonging to $B$. cereus phylogenetic groups II-VII was studied for their capacity to sporulate in anaerobiosis. In addition, spores of the strain AH187 from group III were study for heat resistance, chemical resistance, germination capacity, spore size and structure.

\section{Materials and methods}

\subsection{Strains and media}

A collection of $18 \mathrm{~B}$. cereus strains was selected for this study (Table 1). These strains belong to phylogenetic groups II, III, IV, V, VI and VII as defined by Guinebretiere et al. (2008). The chemically defined medium MOD, previously described by Glatz and Goepfert (1977) was optimized for the growth and sporulation of $B$. cereus strains. MOD medium was first supplemented with $5.74 \mathrm{mM}$ $\mathrm{K}_{2} \mathrm{HPO}_{4}, 45.4 \mathrm{mM}\left(\mathrm{NH}_{4}\right)_{2} \mathrm{SO}_{4}$, and $0.16 \mathrm{mM} \mathrm{MgSO}_{4}$ (Duport et al., 2004). This medium (MODs) was then quarter-diluted and supplemented with $0.5 \mathrm{mM} \mathrm{MgCl}, 0.01 \mathrm{mM} \mathrm{MnCl}, 0.05 \mathrm{mM} \mathrm{ZnCl}_{2}$, and $0.2 \mathrm{mM} \mathrm{CaCl}_{2}$. MODs was finally adjusted to $\mathrm{pH} 7.2$ with $\mathrm{KOH}$.
Table 1

Characteristics of the studied strains.

\begin{tabular}{|c|c|c|c|c|}
\hline \multirow[t]{2}{*}{ Strain designation } & \multirow[t]{2}{*}{ Origin } & \multicolumn{2}{|c|}{$\begin{array}{l}\text { Temperature } \\
\text { growth limits } \\
\left(\mathrm{C}^{\circ}\right)\end{array}$} & \multirow[t]{2}{*}{$\begin{array}{l}\text { Phylogenetic } \\
\text { group }^{\text {a }}\end{array}$} \\
\hline & & Lower & Upper & \\
\hline D15 & Diarrhoeal outbreak & \multirow{3}{*}{7} & \multirow{3}{*}{40} & II \\
\hline INRA KBAA5 & Soil & & & II \\
\hline INRA 15 & Food & & & II \\
\hline AH187 & Emetic outbreak & \multirow{3}{*}{15} & \multirow{3}{*}{45} & III-5 \\
\hline F837/76 & Clinical infection & & & III-8 \\
\hline F4433/73 & Diarrhoeal outbreak & & & III-12 \\
\hline $\mathrm{F} 4430 / 73$ & Diarrhoeal outbreak & \multirow{3}{*}{10} & \multirow{3}{*}{$40 / 45$} & IV-3 \\
\hline ATCC14579 & Type strain $B$. cereus & & & IV-3 \\
\hline NVH1230 & & & & \\
\hline F2769/77 & Diarrhoeal outbreak & \multirow{3}{*}{10} & \multirow{3}{*}{40} & V \\
\hline NVH 141/1-01 & Diarrhoeal outbreak & & & V \\
\hline UHDAM TSP9 & Environment & & & V \\
\hline INRA KBAB4 & Environment & \multirow{3}{*}{$5 / 7$} & \multirow{3}{*}{37} & VI-1 \\
\hline WSBC 10688 & Environment & & & VI-2 \\
\hline WSBC 10204T & Type strain $B$. weihens. & & & VI-1 \\
\hline NVH883/00 & Diarrhoeal outbreak & \multirow{3}{*}{20} & \multirow{3}{*}{50} & VII \\
\hline AFSSA 08CEB44bac & Diarrhoeal outbreak & & & VII \\
\hline NVH 391-98 & Diarrhoeal outbreak & & & VII \\
\hline
\end{tabular}

a The phylogenetic groups to which they belong in the B. cereus group as defined by Guinebretiere et al. (2008).

For the growth of group VII strains, $4.8 \mathrm{mM}$ tryptophan was added to the medium because of their auxotrophy for this amino acid. After autoclave sterilization, MODs was supplemented with $10 \mathrm{mM}$ glucose as a fermentative carbon source. For uncontrolled batch culture, $80 \mathrm{mM} \mathrm{K}_{2} \mathrm{HPO}_{4}$ and $20 \mathrm{mM} \mathrm{KH}_{2} \mathrm{PO}_{4}$ were used to buffer the medium.

\subsection{Uncontrolled batch cultures}

Overnight cultures of $B$. cereus strains were run in MOD supplemented with $30 \mathrm{mM}$ glucose with stirring (200 rpm). Incubation was performed at $30{ }^{\circ} \mathrm{C}$ for strains belonging to phylogenetic groups II, V and VI, and $37{ }^{\circ} \mathrm{C}$ for strains belonging to phylogenetic groups III, IV and VII. After incubation for $18 \mathrm{~h}$, each culture was centrifuged at $7000 \mathrm{~g}$ for $5 \mathrm{~min}$ at room temperature, and cells were suspended in MODs medium. For anaerobic experiments, cultures were run in Hungate tubes equipped with open-top caps and rubber septa, and filled with $12 \mathrm{ml}$ MODs. To eliminate any traces of oxygen, a flow of $\mathrm{N}_{2}$ sent through a Hungate column was sparged into the medium. Aerobic cultures were performed in $250 \mathrm{ml}$ conical flasks containing $50 \mathrm{ml}$ MODs. Cultures were performed in triplicate.

\subsection{Controlled batch cultures}

B. cereus AH187 cells from overnight cultures in MOD medium, were centrifuged at $7000 \mathrm{~g}$ for $5 \mathrm{~min}$ at room temperature, washed twice and resuspended in MODs medium. A $2 \mathrm{~L}$ bioreactor (Inceltech Discovery 100 (Toulouse, France) containing 1.3 L of MODs medium was inoculated at an initial $A_{600}$ value of 0.05 in MODs with this suspension. Temperature was regulated at $37{ }^{\circ} \mathrm{C}$. For aerobic conditions, agitation was adjusted to maintain the partial pressure of oxygen $\left(\mathrm{pO}_{2}\right)$ above $60 \%$. Bioreactors were kept under airflow to obtain aerobiosis, or nitrogen flow to obtain anaerobiosis. The $\mathrm{pH}$ was regulated at 7.2 by adding $2 \mathrm{M} \mathrm{KOH}$ or $2 \mathrm{M} \mathrm{HCl}$. The regulated batch was equipped with a polarographic oxygen electrode (Mettler Toledo) calibrated in a medium flushed with air 
( $100 \%$ value) or pure $\mathrm{N}_{2}$ ( $0 \%$ value). Each condition was used in three independent experiments.

\subsection{Spore production}

Spore formation was monitored in uncontrolled and controlled batch cultures using a phase contrast microscope (Olympus BX 50 instrument, Rungis, France). When free phase-bright spores were obtained, harvesting and purification of spores was performed at $4{ }^{\circ} \mathrm{C}$ to prevent germination. The culture was first centrifuged at $8500 \mathrm{~g}$ for $15 \mathrm{~min}$, then washed with cold distilled water and centrifuged with decreasing rotor speeds $(8500 \mathrm{~g}, 6500 \mathrm{~g}$ and $5500 \mathrm{~g}$ ) for $15 \mathrm{~min}$. The pellet of spores obtained from each centrifugation was suspended in cold distilled water. After harvesting, the spores were pasteurized at $70{ }^{\circ} \mathrm{C}$ for $10 \mathrm{~min}$ to eliminate any vegetative cells, and then cooled in an ice bath. Spore suspensions were stored at $4{ }^{\circ} \mathrm{C}$ until use.

\subsection{Cell and spore counts}

Concentration of vegetative cells and spores was determined, directly and after heating at $70{ }^{\circ} \mathrm{C}$ for $10 \mathrm{~min}$ to kill any vegetative cells, respectively. Serial decimal dilutions of cultures were made in $0.1 \mathrm{M}$ phosphate buffer, $\mathrm{pH}$ 7.0. An aliquot of $100 \mu \mathrm{l}$ of each dilution was plated on LB-agar medium and incubated at $30{ }^{\circ} \mathrm{C}$ for $24 \mathrm{~h}$. Cells and spores concentration was expressed as colony-forming units per $\mathrm{ml}\left(\mathrm{CFU} \mathrm{ml} \mathrm{m}^{-1}\right.$ ).

\subsection{Resistance of B. cereus spores produced in controlled batch cultures}

\subsubsection{Spore wet-heat resistance}

Spores of strain AH187 produced in the absence and presence of oxygen were heated for $10 \mathrm{~min}$ at $70{ }^{\circ} \mathrm{C}$ and then cooled on ice for 15 min to determine initial spore numbers. Wet-heat resistance were performed at $90^{\circ} \mathrm{C}, 92.5^{\circ} \mathrm{C}, 95^{\circ} \mathrm{C}, 97.5^{\circ} \mathrm{C}$ and $100{ }^{\circ} \mathrm{C}$ in order to evaluate a $z$-value of spores produced in the two conditions. $D_{\mathrm{T}}$ values were determined for each temperature as the time necessary to reduce one $\log _{10}$ cycle of the population. The linear model was used to determine $D_{\mathrm{T}}$ values: $\left(\log N=\log N_{0}-t / D_{\mathrm{T}}\right)$ where $N_{0}$ and $N$ are the initial population and population at time $t$, respectively. $z$-values were determined as the difference in temperature required to increase or reduce tenfold the $D_{\mathrm{T}}$ value by plotting $\log D_{\mathrm{T}}$ as a function of the temperature. $z$-value corresponds to $(-1 / a)$ where " $a$ " is the slope of the curve. Wet-heat resistance was evaluated on a spore suspension in capillary tubes heated and removed at regular intervals as described by Leguerinel et al. (2007).

\subsubsection{Resistance of spores to chemicals, acid and alkali}

Resistance of spores to hydrogen peroxide, formaldehyde, sodium hydroxide and nitrous acid was tested as previously described (Loshon et al., 1986; Setlow et al., 2002; Cortezzo and Setlow, 2005; Rose et al., 2007; Gounina-Allouane et al., 2008; Planchon et al., 2011). Spore suspensions were mixed with $50 \mathrm{mM} \mathrm{KPO}_{4}$, pH 7.4 containing $5 \% \mathrm{H}_{2} \mathrm{O}_{2}$ or $0.25 \mathrm{M}$ formaldehyde, $1 \mathrm{M}$ sodium hydroxide or $0.1 \mathrm{M}$ nitrous acid. Treatment was carried out at room temperature or at $37^{\circ} \mathrm{C}$ for formaldehyde. After incubation, samples were diluted 10 -fold in $50 \mathrm{mM} \mathrm{KPO}_{4}, \mathrm{pH} 7.4$ containing $100 \mathrm{U}$ of bovine catalase (Sigma-Aldrich, Steinheim, Germany) for $\mathrm{H}_{2} \mathrm{O}_{2}$ treatment, $2 \%$ glycine for formaldehyde and $0.1 \mathrm{M} \mathrm{KPO}_{4}, \mathrm{pH} 7.5$ for nitrous acid and sodium hydroxide assays. For each treatment, spore reduction was determined by $\log _{10}\left(N / N_{0}\right)$ where $N_{0}$ is the initial spore population and $N$ the spore population surviving the treatment.

\subsubsection{Ultraviolet and pulsed light treatment}

The UV resistance of spores produced under anaerobiosis or aerobiosis was determined using (i) a pulsed light (PL) instrument (Claranor SA, Manosque, France) delivering short pulses (duration $25 \mu \mathrm{s})$ of broad spectrum white light $(200-1100 \mathrm{~nm})$ rich in UV (200-400 nm), and (ii) a laboratory-made instrument with germicidal lamp tubes (Mazda, Suresnes, France) delivering monochromatic UV-C at wavelength $254 \mathrm{~nm}$. Suspensions of $10^{5}$ $10^{6}$ spores $\mathrm{ml}^{-1}$ were spread on $9.0 \mathrm{~cm}$ diameter Petri dishes of LB agar. Each plate was exposed to pulsed light immediately after spreading the suspension. Fluence corresponds to the total energy received by the contaminated surface and ranged from $0.3 \mathrm{~J} \mathrm{~cm}^{-2}$ to $1.25 \mathrm{~J} \mathrm{~cm}^{-2}$ (delivered in one flash) and $1.8 \mathrm{~J} \mathrm{~cm}^{-2}$ (delivered in two flashes at $1 \mathrm{~s}$ interval) with an input voltage of $2.5 \mathrm{kV}$. The different UV-C fluences were obtained by varying the exposure time. F1 (fluences to $1 \log$ reduction) was calculated using the model of Albert and Mafart (2005), as previously performed. The equation is:

$\log _{10} \frac{N_{\mathrm{F}}}{N_{0}}=\log _{10}\left[\left(1-\frac{N_{\text {res }}}{N_{0}}\right) \times 10^{-\left(F / F_{1}\right)^{p}}+\left(\frac{N_{\text {res }}}{N_{0}}\right)\right]$

where $F$ is the fluence applied $\left(\mathrm{J} \mathrm{cm}^{-2}\right), N_{\mathrm{F}}$ is the number of CFU after treatment at a fluence $F, N_{0}$ is the initial number of CFU, $N_{\text {res }}$ is the residual bacterial number, $F_{1}$ is the fluence allowing the first $\log _{10}$ reduction and $p$ is a parameter which determines the curve convexity or concavity (upward concavity: $p<1$, upward convexity: $p>1$ ). The model determines the last three parameters. Fluences allowing an $n \log _{10}$ reduction were calculated using Eq. (2):

$F_{n}=F_{1}\left[\left(\log _{10}\left(\frac{1-\frac{N_{\text {res }}}{N_{0}}}{10^{-n}-\frac{N_{\text {res }}}{N_{0}}}\right)\right)^{1 / p}\right]$

$F 1, p$ and $N_{0}$ were calculated using the Microsoft ${ }^{\circledR}$ Excel 2010 solver function.

\subsection{Spore germination}

Spore germination was evaluated by the loss of heat resistance. After heat activation for $10 \mathrm{~min}$ at $70{ }^{\circ} \mathrm{C}$, germination was performed in a $10 \mathrm{mM}$ Tris, $10 \mathrm{mM} \mathrm{NaCl}$ buffer ( $\mathrm{pH}$ 7.4) supplemented with different concentrations of inosine or L-alanine. The last germinant was used in combination with $0.2 \mathrm{M}$ D-cycloserine, preventing enzymatic conversion of $\mathrm{L}$-alanine into $\mathrm{D}$-alanine, which is a competitive inhibitor of L-alanine for germination. Germination was followed for $3 \mathrm{~h}$ at $30^{\circ} \mathrm{C}$ in aerobic conditions with shaking. Aliquots were harvested after $3 \mathrm{~h}$, pasteurized for $15 \mathrm{~min}$ at $70^{\circ} \mathrm{C}$ and cooled on ice. The level of germination corresponds to the difference between the initial number of spores $\left(N_{0}\right)$ and the number of non-germinated spores after $3 \mathrm{~h}(N)$, expressed as $\log N /$ $N_{0}$. The percentage of germination was determined using the formula $\left[\left(N_{0}-N\right) / N_{0}\right] \times 100$.

\subsection{Transmission electron microscopy}

Fresh AH187 spores produced in controlled batch cultures, in the absence and presence of oxygen, were examined after negative staining with $1 \%$ ammonium molybdate. Observations were made with a transmission electron microscope (TEM-FEI-PhilipsCM10, Eindhoven, Netherlands). Spore size was determined by measuring spore length and width directly on the image using Image J software, from three independent samples of at least 36 spores for anaerobic and aerobic conditions. For spore section analysis, $200 \mu \mathrm{l}$ of a fresh spore suspension was centrifuged at $7000 \mathrm{~g}$ for $5 \mathrm{~min}$ and fixed for $1 \mathrm{~h}$ at room temperature with $2.5 \%$ of glutaraldehyde in 
$0.1 \mathrm{M}$ sodium cacodylate buffer $\mathrm{pH} 7.2$, containing $1 \mathrm{mg} \mathrm{ml} \mathrm{m}^{-1}$ ruthenium red. After incubation, the spores were washed three times with $0.2 \mathrm{M}$ of sodium cacodylate and post-fixed for $1 \mathrm{~h}$ at room temperature with $2 \%$ osmium tetroxide under a fume hood. Samples were washed in water and mixed with $30 \%$ ethanol. After centrifugation, spore pellets were embedded in 3\% agar and submitted to successive dehydration baths with increasing concentrations of ethanol under shaking (70\%, 90\% and 100\%). Ethanol was replaced with propylene oxide and sequentially exchanged with araldite resin. Samples were polymerized for $48 \mathrm{~h}$ at $60^{\circ} \mathrm{C}$. Thin sections (width $60 \mathrm{~nm}$ ) were cut with an ultramicrotome (Leica, France) and stained with $2 \%$ uranyl acetate and lead citrate. Observations were made with a transmission electron microscope (TEM e FEI-PhilipsCM10, Eindhoven, Netherlands).

\subsection{Dipicolinique acid DPA content}

DPA content was measured by a colorimetric assay (Rotman and Fields, 1967). DPA was extracted from spore suspensions $\left(A_{600}\right.$ of 1.0) by autoclaving at $121{ }^{\circ} \mathrm{C}$ for $30 \mathrm{~min}$ and then cooling. Autoclaved suspensions were centrifuged at $7000 \mathrm{~g}$ for $15 \mathrm{~min}$ at room temperature. A $0.8 \mathrm{ml}$ volume of samples was mixed with $0.2 \mathrm{ml}$ of reagent composed of $1 \%\left(\mathrm{w} \mathrm{vol}^{-1}\right)$ ammonium iron (II) sulphate Fe $\left(\mathrm{NH}_{4}\right)_{2}\left(\mathrm{SO}_{4}\right)_{2} 6 \mathrm{H}_{2} \mathrm{O}$ and $0.1 \%\left(\mathrm{w} \mathrm{vol}{ }^{-1}\right)$ cystein in sodium acetate buffer $0.05 \mathrm{M}, \mathrm{pH} 4.0$. Then, $A_{400}$ was measured to determine the DPA concentration via a calibration curve using a $5 \mu \mathrm{g} \mathrm{ml}^{-1} \mathrm{DPA}$ solution. Spore DPA content was expressed in $\mathrm{mg}$ per unit of the initial $A_{600}$ of spore suspensions.

\subsection{Statistical analysis}

A Student $t$-test was used to analyze differences for cell growth and sporulation capacity in aerobiosis and anaerobiosis conditions, assuming unequal variances and using the Microsoft ${ }^{\circledR}$ Excel 2010 analytical tool.

\section{Results}

\subsection{Growth and sporulation capacity of B. cereus strains in uncontrolled batch culture}

Eighteen strains belonging to the different phylogenetic groups of $B$. cereus were selected to cover the phenotypic diversity of $B$. cereus strains (Table 1 ). Their growth and ability to sporulate in MODs were tested in aerobic and anaerobic conditions.

The final biomass, measured in stationary growth phase by cell counting, is expressed as CFU ml ${ }^{-1}$ (Fig. 1). In aerobiosis, the final biomass was similar for all tested strains, and ranged from about $2.95 \times 10^{8} \mathrm{CFU} \mathrm{ml}{ }^{-1}$ to $3 \times 10^{9} \mathrm{CFU} \mathrm{ml}^{-1}$ (Fig. 1A). No growth was observed for the three strains belonging to phylogenetic group VII, presumably because this group requires more nutrients for growth than those present in the MODs medium. In anaerobiosis, the average final biomass was lower than in aerobiosis, ranging from $2 \times 10^{6} \mathrm{CFU} \mathrm{ml}{ }^{-1}$ for the UHDAM TSP9 strain (group V) to $10^{8} \mathrm{CFU}$ $\mathrm{ml}^{-1}$ for the ATCC 14579 strain (group IV). No correlation between ability to grow under anaerobic conditions and phylogenetic group was observed.

The capacity to sporulate in aerobiosis or anaerobiosis was evaluated by spore counting after heating the cell suspension (Fig. 1B). In the presence of oxygen, all the strains sporulated, with an average of $8 \times 10^{8}$ spores $\mathrm{ml}^{-1}$, corresponding to a sporulation rate of $77 \pm 3.93 \%$. Similar results were obtained in CCY sporulation medium, which is frequently used for Bacillus sporulation (data not shown). In anaerobiosis, strains displayed lower sporulation ability than in aerobiosis, with an average of $5 \times 10^{4}$ spores $\mathrm{ml}^{-1}$,

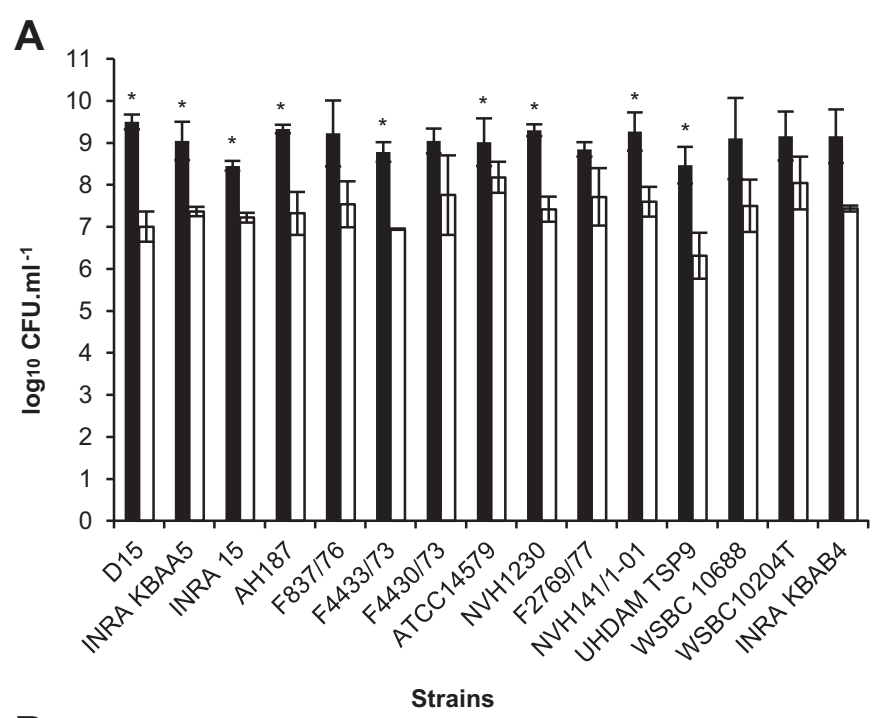

B

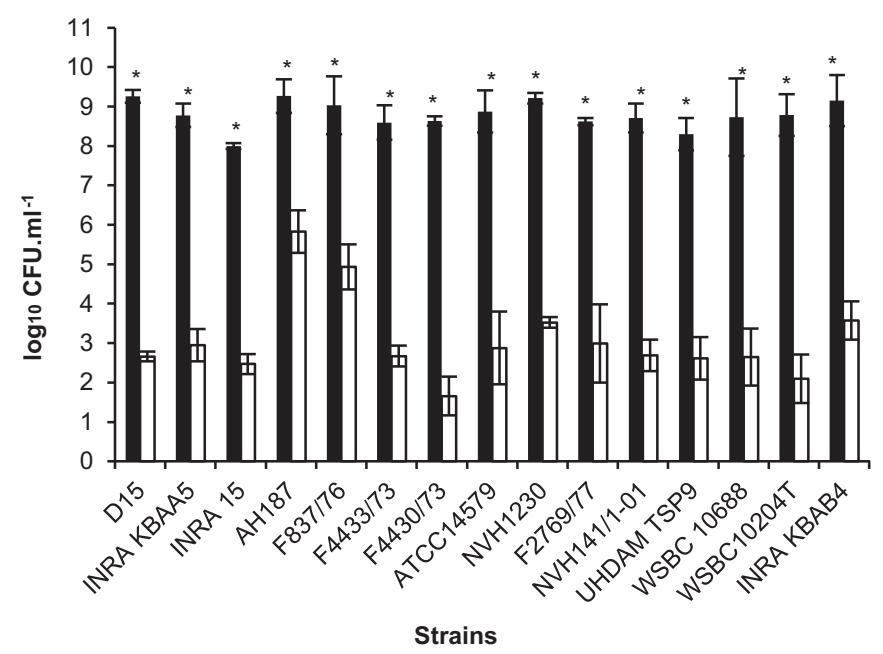

Fig. 1. Growth (A) and sporulation (B) of 15 strains of $B$. cereus in MODs medium in aerobiosis and anaerobiosis at $30^{\circ} \mathrm{C}$ for strains of groups II, V, VI and at $37^{\circ} \mathrm{C}$ for strains of groups III, IV, VII. Number of total cells (A) and total spores (B) (CFU ml ${ }^{-1}$ ) in aerobiosis $(\boldsymbol{\square})$ and in anaerobiosis $(\square)$. Means labeled with $\left(^{*}\right)$ were significantly different at $P<0.05$ (Student's $t$-test)

corresponding to a $0.26 \pm 0.17 \%$ sporulation rate. In addition, high heterogeneity among the strains was observed. The highest amount of spores produced was $6.75 \times 10^{5}$ spores $\mathrm{ml}^{-1}$ for the strain AH187 and the lowest amount was $2.73 \times 10^{1}$ spores $\mathrm{ml}^{-1}$ for the F4430/73 strain. No correlation was noted between sporulation capacity and phylogenetic group. The B. cereus AH187 strain was chosen for further characterization of sporulation and spore properties because this strain was the best spore producer in the absence of oxygen among the tested strains.

\subsection{Growth and sporulation of B. cereus strain AH187 in controlled batch culture}

Aerobic or anaerobic growth of $B$. cereus AH187 was carried out in controlled batch culture with MODs medium at $\mathrm{pH} 7.2$ and temperature $37^{\circ} \mathrm{C}$. In aerobiosis, final biomass was obtained after $10 \mathrm{~h}$ of culture and was about $10^{9} \mathrm{CFU} \mathrm{ml}{ }^{-1}$. In anaerobiosis, final biomass was lower than in aerobiosis $\left(10^{7} \mathrm{CFU} \mathrm{ml} \mathrm{m}^{-1}\right)$, and was obtained after $8 \mathrm{~h}$ of incubation (Fig. 2). Endospore formation and 
Version définitive du manuscrit publiée dans / Final version of the manuscript published in :

Food Microbiology (2014), Vol. 42, p. 122-131, DOI: 10.1016/j.fm.2014.03.004

Journal homepage: http://www.elsevier.com/locate/fm

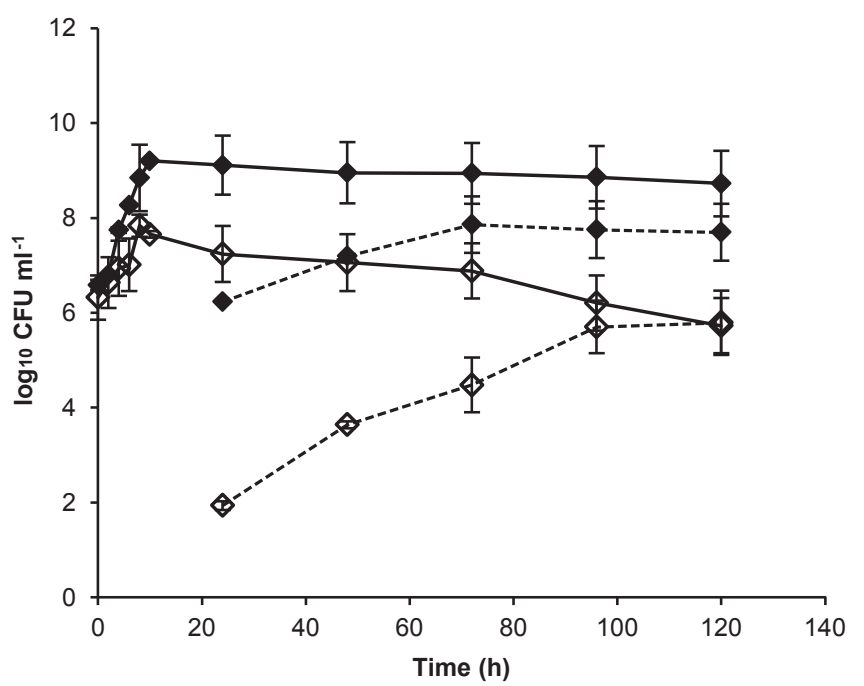

Fig. 2. Growth and sporulation of $B$. cereus AH187 in MODs media in anaerobiosis and aerobiosis at $37{ }^{\circ} \mathrm{C}$. Number of total cells (continuous line) and total spores (dashed line) (CFU ml ${ }^{-1}$ ) in aerobiosis (filled symbols) and in anaerobiosis (open symbols).

spores released from sporangium (free spores) were followed during the culture by phase contrast microscopic observation and cell counting. The first endospores were observed $10 \mathrm{~h}$ after cell inoculation both in the presence and in the absence of oxygen, but were probably not mature because no form of resistance was counted at either time. The first free spores were released $24 \mathrm{~h}$ after cell inoculation in both atmospheric conditions (Fig. 2). Maximum spore production in aerobiosis was higher than in anaerobiosis. It was about $10^{8}$ spores $\mathrm{ml}^{-1}$ and $10^{6}$ spores $\mathrm{ml}^{-1}$, respectively. Spores were harvested after 5 days in both conditions.

\subsection{Spore resistance}

\subsubsection{Spore wet-heat resistance}

Spore wet-heat resistance at $90{ }^{\circ} \mathrm{C}, 92.5{ }^{\circ} \mathrm{C}, 95^{\circ} \mathrm{C}, 97.5^{\circ} \mathrm{C}$ and $100{ }^{\circ} \mathrm{C}$ was followed for $60-80 \mathrm{~min}$. The mean $D_{\mathrm{T}}$-values determined for spores produced in the two tested conditions are shown in Table 2. These results show that the AH187 spores produced in the absence of oxygen were significantly more heat-resistant than those produced in its presence. The most important difference in $D$ value between spores produced in both conditions was at $90{ }^{\circ} \mathrm{C}$ where spores obtained in anaerobiosis were highly heat resistant $\left(D_{90^{\circ} \mathrm{C}}=81.87 \pm 2 \mathrm{~min}\right)$ compared to spore obtained in aerobiosis $\left(D_{90^{\circ} \mathrm{C}}=21.09 \pm 1.70 \mathrm{~min}\right)$. This difference decreased greatly with increasing temperature.

Spores produced in aerobiosis have a $z$-value of $10.52{ }^{\circ} \mathrm{C}$ compared with $7.74{ }^{\circ} \mathrm{C}$ for spores produced in anaerobiosis (Table 2 , Fig. 3). High determination coefficients $\left(R^{2}\right)$ were obtained for all cases.

\subsubsection{Spore chemicals, acid and alkali resistance}

The level of resistance to sodium hydroxide, nitrous acid, hydrogen peroxide and formaldehyde of $B$. cereus AH187 spores produced in anaerobiosis and aerobiosis was determined. The

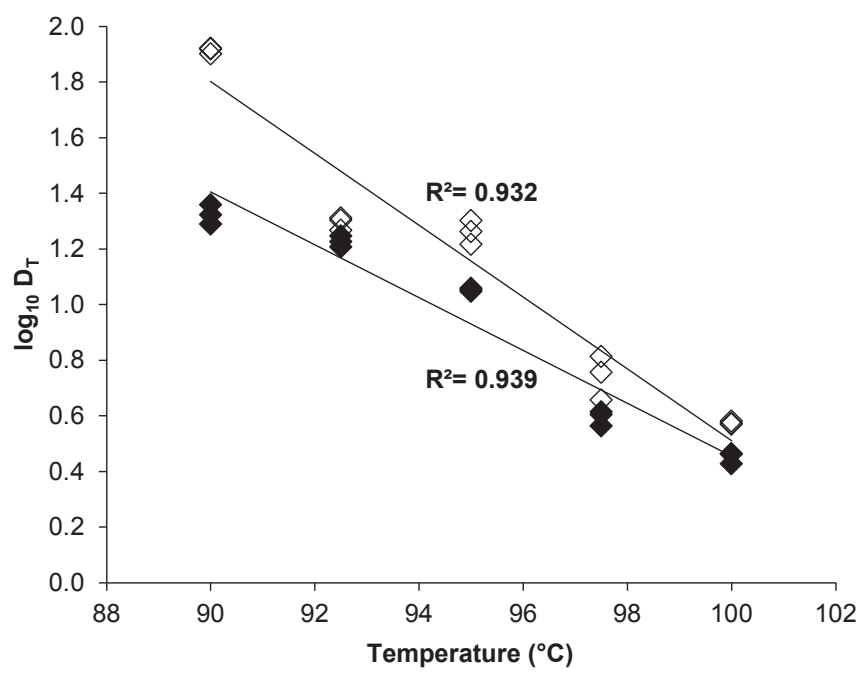

Fig. 3. Decimal reduction time curves of B. cereus AH 187 strain in aerobiosis (open symbols) and anaerobiosis (filled symbols).

number of spores surviving after 60 min incubation with $\mathrm{NaOH}$ was $2.67 \pm 0.22 \log _{10} \mathrm{CFU} \mathrm{ml} \mathrm{m}^{-1}$ for spores formed under aerobiosis and $1.82 \pm 0.42 \log _{10}$ CFU ml ${ }^{-1}$ under anaerobiosis (Fig. 4A), showing that spores produced under anaerobiosis were significantly more resistant to sodium hydroxide. Spores produced under anaerobiosis were significantly more resistant to nitrous acid, with a reduction of only $0.79 \pm 0.28 \log _{10} \mathrm{CFU} \mathrm{ml} \mathrm{m}^{-1}$ after $120 \mathrm{~min}$ incubation, compared with $3.35 \pm 0.35 \log _{10} \mathrm{CFU} \mathrm{ml} \mathrm{m}^{-1}$ for spores produced under aerobiosis (Fig. 4B). No significant difference in hydrogen peroxide and formaldehyde resistance was observed between the two conditions of sporulation (Fig. 4C and D).

\subsubsection{Resistance of spores to pulsed light (PL) and $U V$}

Under PL treatment, increasing fluence was followed by a decrease in spore survival in both conditions studied. For a fluence of $0.34 \mathrm{~J} \mathrm{~cm}^{-2}$, spores produced under anaerobiosis and aerobiosis gave a $0.11 \pm 0.04 \log _{10} \mathrm{CFU} \mathrm{ml} \mathrm{m}^{-1}$ reduction and a $0.74 \pm 0.26$ $\log _{10}$ CFU ml ${ }^{-1}$ reduction, respectively. For a fluence of $0.49 \mathrm{~J} \mathrm{~cm}^{-2}$, a $0.38 \pm 0.05 \log _{10} \mathrm{CFU} \mathrm{ml} \mathrm{m}^{-1}$ reduction and a $0.95 \pm 0.22 \log _{10} \mathrm{CFU}$ $\mathrm{ml}^{-1}$ reduction were obtained under anaerobiosis and aerobiosis, respectively. These results show that, for these two fluences, spores produced under anaerobiosis were more resistant to PL than those produced under aerobiosis (Fig. 5A). No significant difference was observed between the two sporulation conditions for UV-C at $254 \mathrm{~nm}$ continuous illumination (Fig. 5B).

\subsection{Spore germination}

B. cereus AH187 spore germination in the presence of inosine or L-alanine was followed by loss of heat resistance of the germinated spores after $3 \mathrm{~h}$ of incubation because for L-alanine, spores produced in anaerobiosis do not reach the maximum rate of germination after $60 \mathrm{~min}$ of incubation (data not shown). For alanineinduced germination, the maximum germination rate $(94.27 \pm 1.97 \%)$ was obtained for a concentration of $10 \mathrm{mM}$ alanine

Table 2

Mean DT-values (min) obtained for spores of B. cereus AH 187 strain produced in aerobiosis and anaerobiosis.

\begin{tabular}{|c|c|c|c|c|c|c|c|}
\hline Condition & $\mathrm{D}_{90}$ & $\mathrm{D}_{92.5}$ & $D_{95}$ & $\mathrm{D}_{97.5}$ & $\mathrm{D}_{100}$ & $z$-Value $\left({ }^{\circ} \mathrm{C}\right)$ & Coefficient $R^{2}$ \\
\hline Aerobiosis & $21.09 \pm 1.70$ & $16.85 \pm 0.77$ & $11.29 \pm 0.14$ & $3.94 \pm 0.24$ & $2.83 \pm 0.13$ & 10.52 & 0.939 \\
\hline Anaerobiosis & $81.87 \pm 2.00$ & $19.68 \pm 1.04$ & $18.25 \pm 1.79$ & $5.58 \pm 0.99$ & $3.76 \pm 0.05$ & 7.74 & 0.932 \\
\hline
\end{tabular}


Version définitive du manuscrit publiée dans / Final version of the manuscript published in :

Food Microbiology (2014), Vol. 42, p. 122-131, DOI: 10.1016/j.fm.2014.03.004

Journal homepage: http://www.elsevier.com/locate/fm
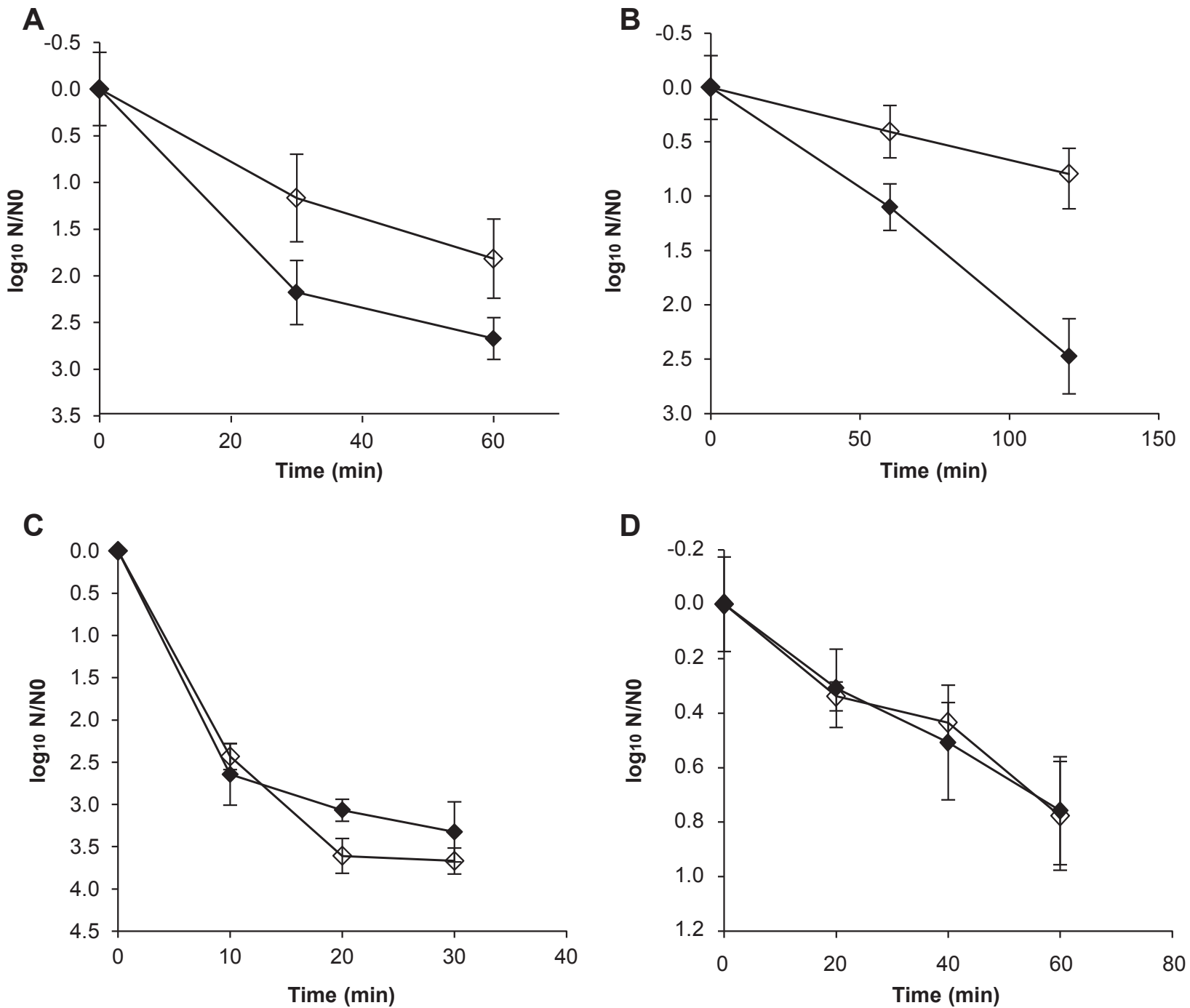

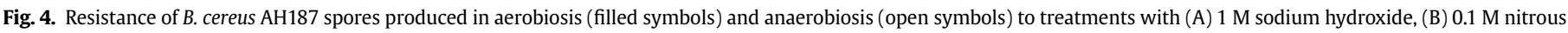

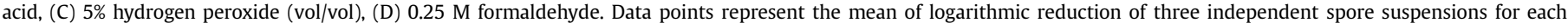
condition.

for spores produced in anaerobiosis (Fig. 6A). The maximum germination $(58.39 \pm 8.57 \%)$ was obtained for spores produced in aerobiosis for a concentration of $200 \mathrm{mM}$ alanine (Fig. 6A). The greatest difference was obtained with $10 \mathrm{mM}$ of alanine, where the percentage of germination was twice as high for spores produced in anaerobiosis than for spores produced in aerobiosis (Fig. 6A). Whatever the alanine concentration, spores produced in anaerobiosis germinated more efficiently than spores produced in aerobiosis. For inosine-induced germination, maximum germination of spores was obtained for a concentration of $1 \mathrm{mM}$ inosine under anaerobiosis and aerobiosis with similar germination rate ( $76 \pm 12 \%$ and $84 \pm 12 \%$, respectively). No significant difference in germination was observed between spores produced in anaerobiosis and in aerobiosis at different concentrations of inosine (Fig. 6B).

\subsection{Spore size, morphology and structure}

Microscopic observations were made after negative staining from three independent samples of at least 36 spores for anaerobic and aerobic conditions of the B. cereus AH187 strain. Spores of AH187 strain obtained in anaerobiosis had an average length of
$1.92 \pm 0.32 \mu \mathrm{m} v s .1 .97 \pm 0.23 \mu \mathrm{m}$ when produced in aerobiosis. The spore width was $0.85 \pm 0.44 \mu \mathrm{m}$ and $0.95 \pm 0.11 \mu \mathrm{m}$, respectively. Thus lengths and widths of spores produced in anaerobiosis or in aerobiosis showed no significant difference. For spores produced in anaerobiosis, 68\% displayed a damaged exosporium or completely separated exosporium with free exosporium fragments (Fig. 7A). Under aerobiosis conditions, only $13 \%$ of spores had a damaged exosporium (Fig. 7B). These results were confirmed by spore ultrastructure analyzed on cross-sections (Fig. 7C-F).

\subsection{DPA contents}

The DPA content was significantly lower in spores produced under aerobic condition $\left(32.76 \pm 12.05 \mu \mathrm{g} / A_{600}\right)$ than in spores produced under anaerobic condition $\left(73.31 \pm 18.03 \mu \mathrm{g} / A_{600}\right)$.

\section{Discussion}

Environmental parameters such as temperature, $\mathrm{pH}$, aeration, minerals and carbon, nitrogen and phosphorus sources are among the major factors influencing the sporulation process (Carlin, 2011). It is known that under aerobic conditions, entry into the stationary 
Version définitive du manuscrit publiée dans / Final version of the manuscript published in :

Food Microbiology (2014), Vol. 42, p. 122-131, DOI: 10.1016/j.fm.2014.03.004

Journal homepage: http://www.elsevier.com/locate/fm
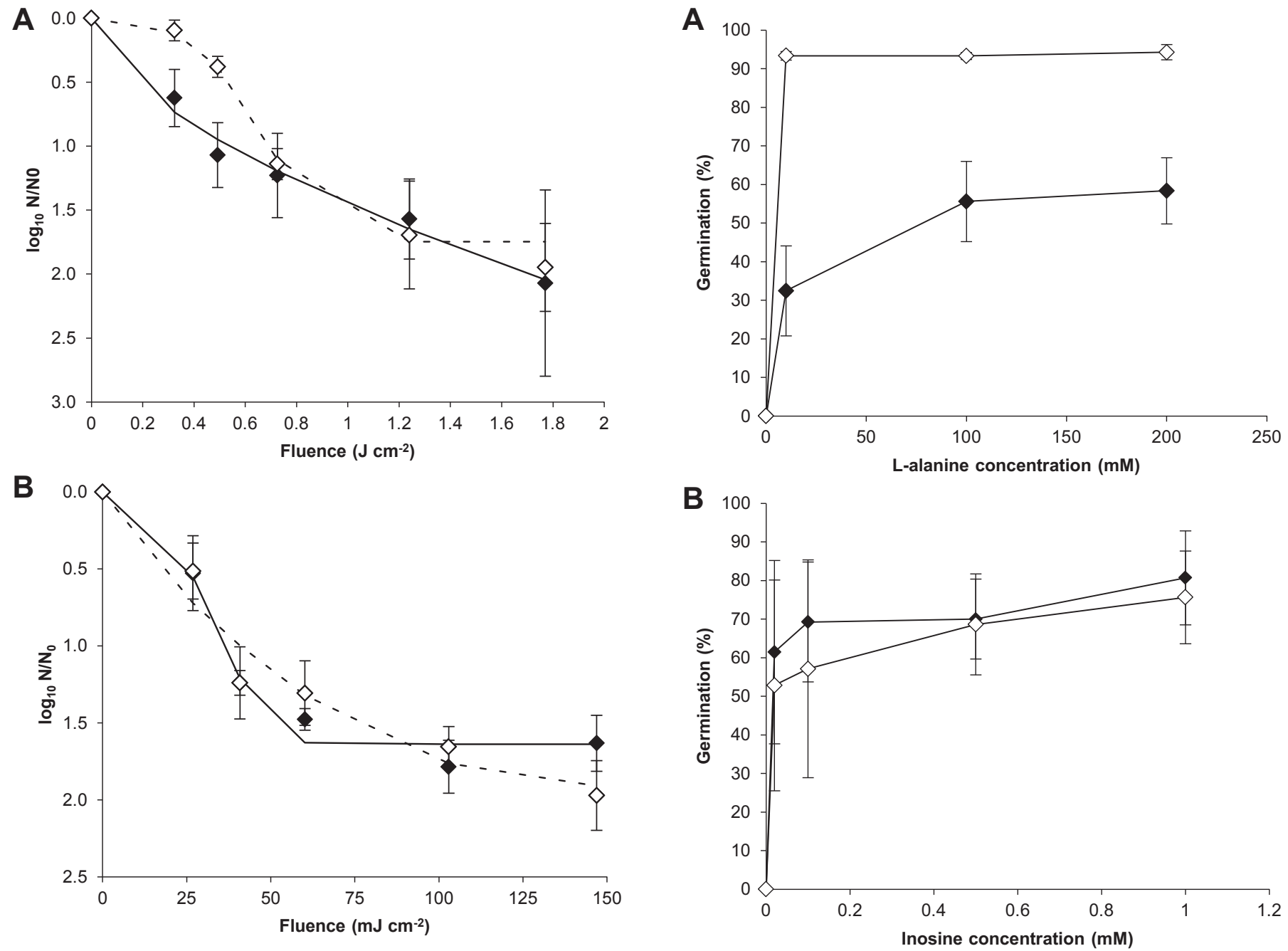

Fig. 5. Resistance of B. cereus AH187 spores to pulsed light (A) and to UV continuous light (B). Data points represent the mean of logarithmic reduction of three independent spore suspensions prepared in aerobiosis (filled symbols) and anaerobiosis (open symbols). The continuous line and discontinuous line represent the fitting of the experimental data (lozenge forme) to the model of Albert and Mafart (2005) in aerobiosis and anaerobiosis, respectively.

phase is caused by progressive nutrient limitation, which finally leads to sporulation in bacilli (Cortezzo and Setlow, 2005; Higgins and Dworkin, 2012). High cell density combined with nutrient depletion is required to trigger sporulation (Grossman, 1995).

Since little information was available on $B$. cereus sporulation in the absence of oxygen, we first optimized an existing medium, MOD, to allow effective growth and sporulation in the absence and presence of oxygen. The chemically defined medium MOD has frequently been used for growth and molecular studies in B. cereus species (Duport et al., 2004). This medium supports anaerobic growth of $B$. cereus strains, but was not effective for sporulation (data not shown). Thus, minerals necessary for development of spores into bacilli (Palop et al., 1999) were added to this medium, giving the MODs medium.

The $B$. cereus group consists of seven phylogenetically close species classified into seven phylogenetic groups, each with its own range of growth temperature (Guinebretiere et al., 2008, 2013). In our study, the sporulation capacity of $18 \mathrm{~B}$. cereus strains belonging to groups II to VI was compared in MODs medium in anaerobic and aerobic conditions. For all tested strains, the lowest spore counts were obtained in anaerobic conditions. This agrees with previous

Fig. 6. Germination of $B$. cereus $A H 187$ spores formed in aerobiosis (filled symbols) and anaerobiosis (open symbols) in response to L-alanine (A) and inosine (B) after incubation for $3 \mathrm{~h}$ at $30 \mathrm{C}$. The percentage of germination was determined using the formula: $\left[\left(N_{0}-N\right) / N_{0}\right] \times 100$ as described in Materials and methods.

results obtained on several species of the genus Bacillus (Couchot and Maier, 1974). In this work, 11 facultatively anaerobic species of the genus Bacillus were tested for their ability to sporulate anaerobically on common laboratory media. Results showed that only two species, Bacillus macerans and Bacillus polymyxa, were able to sporulate in the absence of oxygen. B. cereus did not produce spores in this study (Couchot and Maier, 1974). More recent experiments report that under $\mathrm{O}_{2}$ limitation, spore production of $B$. thuringiensis (a species genetically close to $B$. cereus) was lower than in cultures with $\mathrm{O}_{2}$ (Foda et al., 1985; Avignone-Rossa et al., 1992; Finlay et al., 2002). Likewise, Boniolo and coworkers (Boniolo et al., 2012) showed that interrupting the oxygen supply immediately after the end of the exponential growth phase leads to a lower spore production in B. thuringiensis var israelensis (IP-82). In addition, another study established that carrying out one non-aeration period followed by a moderate oxygenation period during the sporulation phase resulted in higher sporulation of $B$. thuringiensis H14 (Sarrafzadeh and Navarro, 2006). In B. cereus, these data mean that once sporulation has been triggered, it will go to completion even if the oxygen supply is interrupted.

Effects of environmental conditions such as temperature, $\mathrm{pH}$, and water activity of the environment on the heat resistance of 
Version définitive du manuscrit publiée dans / Final version of the manuscript published in :

Food Microbiology (2014), Vol. 42, p. 122-131, DOI: 10.1016/j.fm.2014.03.004

Journal homepage: http://www.elsevier.com/locate/fm

A

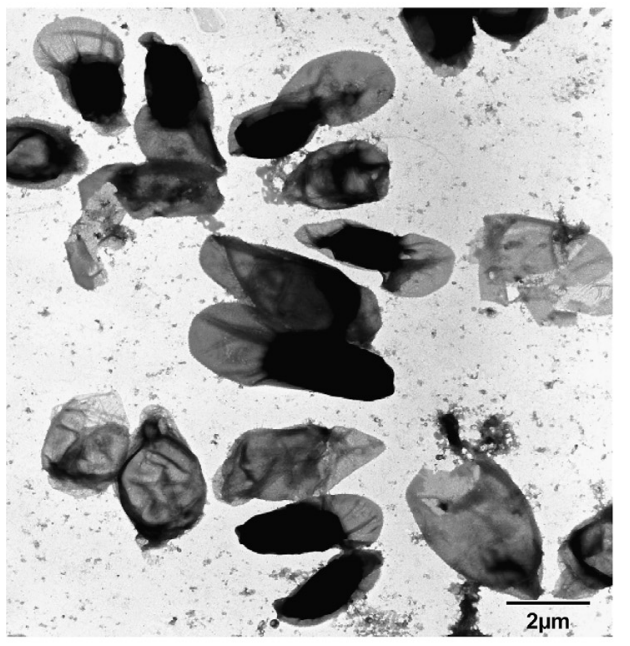

C

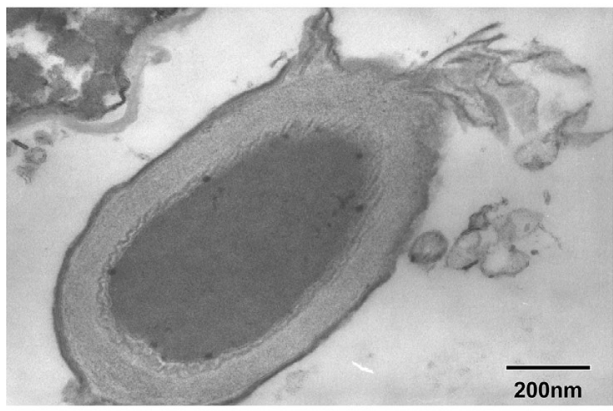

E

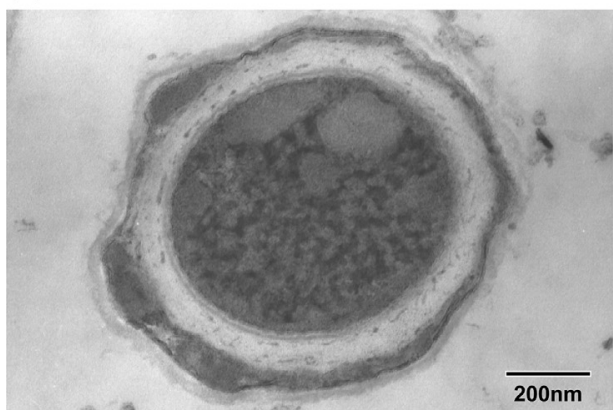

B

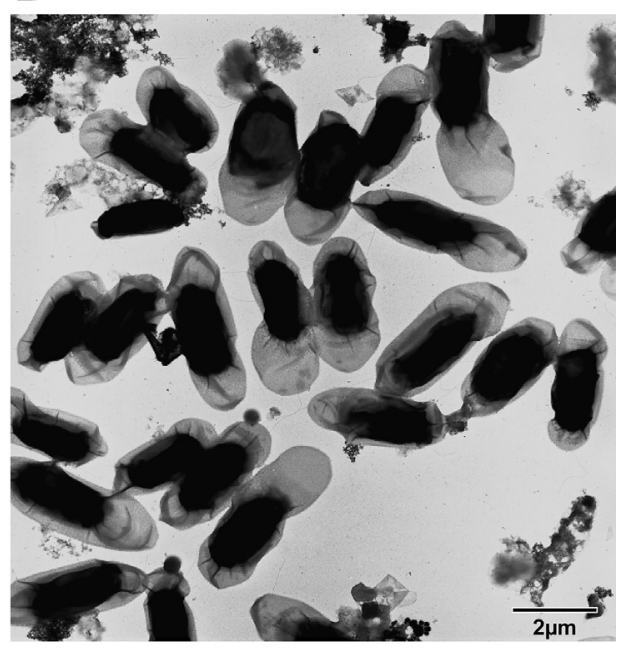

D

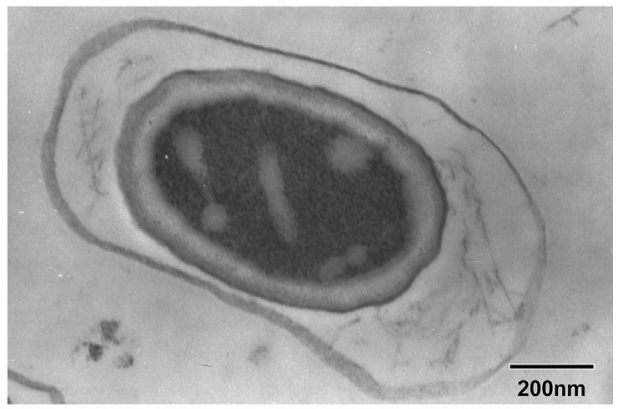

$\mathbf{F}$

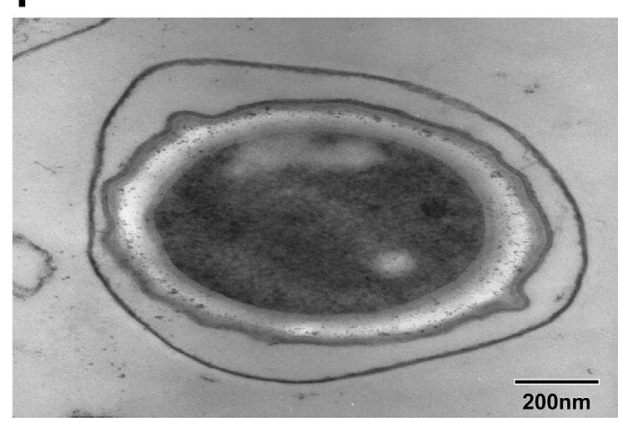

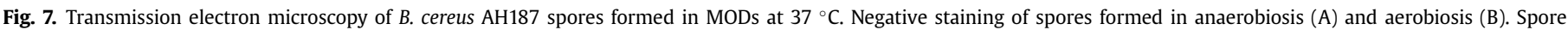
sections in anaerobiosis (C, E) and aerobiosis (D, F).

Bacillus spores have been well documented in previous work (Baweja et al., 2008; Carlin, 2011; Nguyen Thi Minh et al., 2011; Planchon et al., 2011). Overall, spores produced at high temperature, alkaline $\mathrm{pH}$ or low water activity are more resistant to wetheat treatment than those produced at low temperature, acid $\mathrm{pH}$ or high water activity (Melly et al., 2002; Leguerinel et al., 2007; Gounina-Allouane et al., 2008; Nguyen Thi Minh et al., 2011). Data on the effect of anaerobiosis on spore properties of Bacillus species are lacking. In our study, we found that spores of $B$. cereus AH187 produced in anaerobiosis condition were more resistant to wet-heat. The most important difference in $D$ value (about $61 \mathrm{~min}$ ) between spores produced in both conditions was obtained at the lowest temperature $\left(90^{\circ} \mathrm{C}\right)$. At greatest temperature $\left(100{ }^{\circ} \mathrm{C}\right)$ the difference in $D$ values was lowest (about $1 \mathrm{~min}$ ). Moreover, the $z$ value for spores produced in anaerobiosis was lower than for spores produced in aerobiosis. Therefore, the effect of anaerobiosis conditions on the wet-heat resistance decrease as the temperature treatment increase. Several reports have identified some factors playing important roles in spore wet-heat resistance. In addition to dehydration in spore cores, these factors include the level of minerals in spore cores, small acid soluble proteins (SASP), dipicolinic acid (DPA) and membrane fluidity in vegetative cells (Nakashio and Gerhardt, 1985; Beaman and Gerhardt, 1986; Marquis and Shin, 1994; Setlow, 1994; Popham et al., 1995; Nguyen Thi Minh et al., 2011). Our results showed that DPA content was significantly lower in spores produced in aerobiosis than in spores produced in anaerobiosis. This is in agreement with previous studies showing that DPA contribute to lower the spore water content and consequently to increase heat resistance in $B$. subtilis and $B$. cereus (Setlow, 2006; Planchon et al., 2011).

In our study, spores obtained in anaerobiosis conditions were more resistant to nitrous acid ( $0.1 \mathrm{M})$ and sodium hydroxide (1 M) 
than those obtained in aerobiosis. No significant difference was obtained in spore resistance to hydrogen peroxide (5\%), or to formaldehyde $(0.25 \mathrm{M})$. The reason for this could be the presence of the spore coat, which protects spores from some substances such as chlorine dioxide, hypochlorite and hydrogen peroxide (Gould and Hitchins, 1963; Riesenman and Nicholson, 2000; Young and Setlow, 2003). In addition, it has been shown that SASPs play an important role in the resistance of spores to DNA-damaging agents (Setlow, 2006).

Spores of $B$. cereus AH187 produced in aerobiosis were more sensitive than those produced in anaerobiosis to UV treatment delivered by pulsed light (for a fluence of $0.34 \mathrm{~J} \mathrm{~cm}^{-2}$ and $0.49 \mathrm{~J} \mathrm{~cm}^{-2}$ ), whereas no significant difference was observed for continuous UV-C at $254 \mathrm{~nm}$ between the two sporulation conditions. Pulsed light delivers a broad spectrum of visible and UV light (from 100 to $1100 \mathrm{~nm}$ ), and this may explain the differences in destruction efficiency compared with monochromatic UV (Planchon et al., 2011). It has been shown that SASPs protect spores against UV radiation by binding to DNA (Setlow, 2006).

B. cereus AH187 spore germination using alanine as inducer showed that spores produced in anaerobiosis germinated more efficiently than those produced in aerobiosis. According to the literature, spore germination is a complex process under the influence of several factors. For example, it has been shown that a low level of DPA in B. cereus and B. subtilis grown at different temperatures or in medium with various DPA concentrations decreased the capacity of germination (Keynan and Halvorson, 1962; Magge et al., 2008; Planchon et al., 2011). Our results are not in agreement with these studies. In our study, the higher germination rate occurred for spores containing greater DPA concentration. This suggest that another factors are involved in the trigger of germination. In our experimental conditions, the evaluation of spore germination was carried out in atmospheric environment. Therefore, we can hypothesis that oxygen is an important factor in this process.

In addition, previous studies showed that the expression of genes encoding germination proteins was better in Y1 medium, a nutrient-rich, chemically defined sporulation medium, than in modified $G$ medium, containing low amounts of nutrients. The expression of these genes is under the influence of the composition of growth media (Hornstra et al., 2006). The reason for a better germination in anaerobiosis in our study is unknown. It might be attributable to some genes encoding lytic enzymes and/or some other proteins such as the Ger family proteins or those from the exosporium. Interestingly, our study shows that the germination process was better for spores that had lost their exosporium, or spores with a damaged exosporium (anaerobic condition). This suggests an important role of exosporium in the germination process. Severson and co-workers showed that a protein from exosporium (ExsK) played a role in $B$. anthracis germination. In this study, it was shown that (i) a $\Delta$ ExsK mutant spores germinated to a significantly greater extent than did wild type spores, and (ii) no difference in structural exosporium was observed between $\Delta$ ExsK mutant and wild type. The authors suggest that ExsK protein directly or indirectly inhibits germination in response to several germinants (Severson et al., 2009). However, exosporium is composed of approximately 20 proteins, of which few have been characterized. In addition, the role of the exosporium proteins is complex and not clearly elucidated. For inosine-induced germination, maximum germination of spores was obtained for a concentration of $1 \mathrm{mM}$ inosine under anaerobiosis and aerobiosis with similar germination rate. As previously described, inosine was an efficient germinant for $B$. cereus strains, particularly at the highest concentrations ( $1 \mathrm{mM}$ ) (Clements and Moir, 1998; Broussolle et al., 2008). This is in agreement with our results. Indeed, the extent of germination was better with increasing concentration of inosine, as reported by Collado and its collaborators (Collado et al., 2006).

Microscopy has shown that under aerobic condition, only few spores had a damaged or detached exosporium. Previous work showed that the frequency with which spores of $B$. cereus with damaged exosporium were obtained increased when sporulation occurred under less favorable conditions, such as high temperature (Faille et al., 2007). Differences in spore heat resistance, chemical resistance and germination between anaerobic and aerobic conditions suggest a difference in spore structure. However, our results show that spore size (width and lengths) produced in both atmospheric conditions did not vary significantly. Other studies show that environmental parameters such as high and low humidity, and calcium deficiency, affect swell and shrink of spores of B. thuringiensis (Westphal et al., 2003; Nguyen Thi Minh et al., 2011). Our study reports an effect of anaerobiosis on the structure of $B$. cereus $\mathrm{AH} 187$ as visualized by transmission electron microscopy. It can be hypothesized that anaerobiosis is an unfavorable condition, as discussed above, resulting in spores with damaged exosporium.

In conclusion, this work provides new knowledge on the effect of anaerobiosis on spore properties such as resistance, germination and structure in $B$. cereus species. Our study revealed a strong decrease in sporulation rate in the absence of oxygen in $B$. cereus species. One practically important finding is the higher resistance to wet-heat of spores produced anaerobically compared with those produced aerobically. This observation is relevant to food products conserved in anaerobiosis for long periods at refrigerated temperatures, given that $B$. cereus is a food spoilage organism and a foodborne pathogen. Further investigation is needed to determine which sporulation genes are affected during the sporulation process in anaerobiosis.

\section{Acknowledgments}

Amina Aicha Abbas received a fellowship from the Programme Intergouvernemental Franco-Algérien. This work was supported by a grant from the L' Agence Nationale de la Recherche under the project Food-Redox, ANR-11-ALID-001-04.

We thank Dr Frederic Carlin and Dr Véronique Broussolle for helpful discussion (INRA, UMR408 Sécurité et Qualité des Produits d'Origine Végétale, F-84000 Avignon).

We thanks Isabelle Bornard for the microscopic imaging (INRA, Unité de Pathologie Végétale, Laboratoire de microscopie, F-84143 Montfavet), Sabine Mallea and Gérémy Clair for technical assistance and support (INRA, UMR408 Sécurité et Qualité des Produits d'Origine Végétale, F-84000 Avignon).

\section{References}

Albert, I., Mafart, P., 2005. A modified Weibull model for bacterial inactivation. Int. J. Food Microbiol. 100, 197-211.

Andersson, A., Rönner, U., Granum, P.E., 1995. What problems does the food industry have with the spore-forming pathogens Bacillus cereus and Clostridium perfringens. Int. J. Food Microbiol. 28, 145-155.

Avignone-Rossa, C., Arcas, J., Mignone, C., 1992. Bacillus thuringiensis growth, sporulation and $\delta$-endotoxin production in oxygen limited and non-limited cultures. World J. Microbiol. Biotechnol. 8, 301-304.

Baweja, R.B., Zaman, M.S., Mattoo, A.R., Sharma, K., Tripathi, V., Aggarwal, A. Dubey, G.P., Kurupati, R.K., Ganguli, M., Chaudhury, N.K., Sen, S., Das, T.K. Gade, W.N., Singh, Y., 2008. Properties of Bacillus anthracis spores prepared under various environmental conditions. Arch. Microbiol. 189, 71-79.

Beaman, T.C., Gerhardt, P., 1986. Heat-resistance of bacterial-spores correlated with protoplast dehydration, mineralization, and thermal adaptation. Appl. Environ. Microbiol. 52, 1242-1246.

Boniolo, F., Rodrigues, R., Prata, A., López, M., Jacinto, T., Silveira, M., BerbertMolina, M., 2012. Oxygen supply in Bacillus thuringiensis fermentations: bringing new insights on their impact on sporulation and $\delta$-endotoxin production. Appl. Microbiol. Biotechnol. 94, 625-636. 


\section{Version définitive du manuscrit publiée dans / Final version of the manuscript published in : \\ Food Microbiology (2014), Vol. 42, p. 122-131, DOI: 10.1016/j.fm.2014.03.004 \\ Journal homepage: http://www.elsevier.com/locate/fm}

Broussolle, V., Gauillard, F., Nguyen-The, C., Carlin, F., 2008. Diversity of spore germination in response to inosine and L-alanine and its interaction with $\mathrm{NaCl}$ and $\mathrm{pH}$ in the Bacillus cereus group. J. Appl. Microbiol. 105, 1081-1090.

Carlin, F., 2011. Origin of bacterial spores contaminating foods. Food Microbiol. 28, 177-182.

Cazemier, A.E., Wagenaars, S.F.M., TerSteeg, P.F., 2001. Effect of sporulation and recovery medium on the heat resistance and amount of injury of spores from spoilage bacilli. J. Appl. Microbiol. 90, 761-770.

Ceuppens, S., Boon, N.. Uyttendaele, M., 2013. Diversity of Bacillus cereus group strains is reflected in their broad range of pathogenicity and diverse ecological lifestyles. FEMS Microbiol. Ecol. 84, 433-450.

Clavel, T., Carlin, F., Lairon, D., Nguyen-The, C., Schmitt, P., 2004. Survival of Bacillus cereus spores and vegetative cells in acid media simulating human stomach. J. Appl. Microbiol. 97, 214-219.

Clements, M.O., Moir, A., 1998. Role of the gerI operon of Bacillus cereus 569 in the response of spores to germinants. J. Bacteriol. 180, 6729-6735.

Collado, J., Fernandez, A., Rodrigo, M., Martinez, A., 2006. Modelling the effect of a heat shock and germinant concentration on spore germination of a wild strain of Bacillus cereus. Int. J. Food Microbiol. 106, 85-89.

Cortezzo, D.E., Setlow, P., 2005. Analysis of factors that influence the sensitivity of spores of Bacillus subtilis to DNA damaging chemicals. J. Appl. Microbiol. 98, 606-617.

Couchot, K.R., Maier, S., 1974. Anaerobic sporulation in facultatively anaerobic species of the genus Bacillus. Can. J. Microbiol. 20, 1291-1296.

de Vries, Y.P., Atmadja, R.D., Hornstra, L.M., de Vos, W.M., Abee, T., 2005. Influence of glutamate on growth, sporulation, and spore properties of Bacillus cereus ATCC 14579 in defined medium. Appl. Environ. Microbiol. 71, 3248-3254.

Duport, C., Thomassin, S., Bourel, G., Schmitt, P., 2004. Anaerobiosis and low specific growth rates enhance hemolysin BL production by Bacillus cereus F4430/73. Arch. Microbiol. 182, 90-95.

Faille, C., Tauveron, G., Gentil-Lelievre, C.L., Slomianny, C., 2007. Occurrence of Bacillus cereus spores with a damaged exosporium: consequences on the spore adhesion on surfaces of food processing lines. J. Food Prot. 70, 2346-2353.

Finlay, W.J.J., Logan, N.A., Sutherland, A.D., 2002. Bacillus cereus emetic toxin production in relation to dissolved oxygen tension and sporulation. Food Microbiol. 19, 423-430.

Foda, M., Salama, H., Selom, M., 1985. Factors affecting growth physiology of Bacillus thuringiensis. Appl. Microbiol. Biotechnol. 22, 50-52.

Glatz, B.A., Goepfert, J.M., 1977. Production of Bacillus cereus endotoxin in defined media in fermenter-grown cultures. J. Food Prot. 40, 472-474.

Gould, G.W., Hitchins, A.D., 1963. Sensibilization of bacterial spores to lysozyme and to hydrogen peroxide with agents which rupture disulphide bonds. J. Gen. Microb. 33, 413-423.

Gounina-Allouane, R., Broussolle, V., Carlin, F., 2008. Influence of the sporulation temperature on the impact of the nutrients inosine and L-alanine on Bacillus cereus spore germination. Food Microbiol. 25, 544.

Grossman, A.D., 1995. Genetic networks controlling the initiation of sporulation and the development of genetic competence in Bacillus subtilis. Annu. Rev. Genet. 29, 477-508.

Guinebretiere, M.H., Thompson, F.L., Sorokin, A., Normand, P., Dawyndt, P., EhlingSchulz, M., Svensson, B., Sanchis, V., Nguyen-The, C., Heyndrickx, M., De Vos, P., 2008. Ecological diversification in the Bacillus cereus Group. Environ. Microbiol. $10,851-865$

Guinebretiere, M.-H., Auger, S., Galleron, N., Contzen, M., De Sarrau, B., De Buyser, M.-L., Lamberet, G., Fagerlund, A., Granum, P.E., Lereclus, D., De Vos, P., Nguyen-The, C., Sorokin, A., 2013. Bacillus cytotoxicus $s p$ nov is a novel thermotolerant species of the Bacillus cereus Group occasionally associated with food poisoning. Int. J. Syst. Evol. Microbiol. 63, 31-40.

Higgins, D., Dworkin, J., 2012. Recent progress in Bacillus subtilis sporulation. FEMS Microbiol. Rev. 36, 131-148.

Hornstra, L.M., de Vries, Y.P., de Vos, W.M., Abee, T., 2006. Influence of sporulation medium composition on transcription of ger operons and the germination response of spores of Bacillus cereus ATCC 14579. Appl. Environ. Microbiol. 72, $3746-3749$.

Keynan, A., Halvorson, H.O., 1962. Calcium dipicolinic acid-induced germination of Bacillus cereus spores. J. Bacteriol. 83, 100-105.

Leguerinel, I., Couvert, O., Mafart, P., 2007. Modelling the influence of the sporulation temperature upon the bacterial spore heat resistance, application to heating process calculation. Int. J. Food Microbiol. 114, 100-104.

Loshon, C.A., Fliss, E.R., Setlow, B., Foerster, H.F., Setlow, P., 1986. Cloning and nucleotide sequencing of genes for small, acid-soluble spore proteins of Bacillus -cereus, Bacillus stearothermophilus, and Thermoactinomyces thalpophilus. J. Bacteriol. 167, 168-173.

Magge, A., Granger, A.C., Wahome, P.G., Setlow, B., Vepachedu, V.R., Loshon, C.A. Peng, L., Chen, D., Li, Y.-Q., Setlow, P., 2008. Role of dipicolinic acid in the germination, stability, and viability of spores of Bacillus subtilis. J. Bacteriol. 190, 4798-4807.
Margulis, L., Jorgensen, J.Z., Dolan, S., Kolchinsky, R., Rainey, F.A., Lo, S.C., 1998. The Arthromitus stage of Bacillus cereus: intestinal symbionts of animals. Proc. Natl. Acad. Sci. U.S.A. 95, 1236-1241.

Marquis, R.E., Shin, S.Y., 1994. Mineralization and responses of bacterial spores to heat and oxydative agents. FEMS Microbiol. Rev. 14, 375-379.

McKenney, P.T., Driks, A., Eichenberger, P., 2013. The Bacillus subtilis endospore: assembly and functions of the multilayered coat. Nat. Rev. Microbiol. 11, 33-44.

Melly, E., Genest, P.C., Gilmore, M.E., Little, S., Popham, D.L., Driks, A., Setlow, P., 2002. Analysis of the properties of spores of Bacillus subtilis prepared at different temperatures. J. Appl. Microbiol. 92, 1105-1115.

Moir, A., Corfe, B.M., Behravan, J., 2002. Spore germination. Cell. Mol. Life Sci. 59, 403-409.

Nakashio, S., Gerhardt, P., 1985. Protoplast dehydration correlated with heatresistance of bacterial-spores. J. Bacteriol. 162, 571-578.

Nguyen Thi Minh, H., Perrier-Cornet, J.M., Gervais, P., 2008. Effect of the osmotic conditions during sporulation on the subsequent resistance of bacterial spores. Appl. Microbiol. Biotechnol. 80, 107-114.

Nguyen Thi Minh, H., Durand, A., Loison, P., Perrier-Cornet, J.-M., Gervais, P., 2011. Effect of sporulation conditions on the resistance of Bacillus subtilis spores to heat and high pressure. Appl. Microbiol. Biotechnol. 90, 1409-1417.

Nicholson, W.L., 2002. Roles of Bacillus endospores in the environment. Cell. Mol. Life Sci. 59, 410-416.

Palop, A., Sala, F.J., Condon, S., 1999. Heat resistance of native and demineralized spores of Bacillus subtilis sporulated at different temperatures. Appl. Environ. Microbiol. 65, 1316-1319.

Paredes, C.J., Alsaker, K.V., Papoutsakis, E.T., 2005. A comparative genomic view of clostridial sporulation and physiology. Nat. Rev. Microbiol. 3, 969-978.

Paredes-Sabja, D., Setlow, P., Sarker, M.R., 2011. Germination of spores of Bacillales and Clostridiales species: mechanisms and proteins involved. Trends Microbiol. 19, 85-94.

Perez Portuondo, I., 2012. Bacillus cereus and food poisoning. Bacillus cereus y su papel en las intoxicaciones alimentarias. Rev. Cubana Salud Pub. 38, 98-108.

Planchon, S., Dargaignaratz, C., Levy, C., Ginies, C., Broussolle, V., Carlin, F., 2011. Spores of Bacillus cereus strain KBAB4 produced at 10 degrees $C$ and 30 degrees C display variations in their properties. Food Microbiol. 28, 291-297.

Popham, D.L., Sengupta, S., Setlow, P., 1995. Heat, hydrogen peroxide and UV resistance of Bacillus subtilis spores with increased core water content and with or without major DNA-binding proteins. Appl. Environ. Microbiol. 61, 3633-3638.

Riesenman, P.J., Nicholson, W.L., 2000. Role of the spore coat layers in Bacillus subtilis spore resistance to hydrogen peroxide, artificial UV-C, UV-B, and solar UV radiation. Appl. Environ. Microbiol, 66, 620-626.

Rose, R., Setlow, B., Monroe, A., Mallozzi, M., Driks, A., Setlow, P., 2007. Comparison of the properties of Bacillus subtilis spores made in liquid or on agar plates. J. Appl. Microbiol. 103, 691-699.

Rotman, Y., Fields, M.L., 1967. A modified reagent for dipicolinic acid analysis. Anal. Biochem. 22, 168-169.

Sarrafzadeh, M.H., Navarro, J.M., 2006. The effect of oxygen on the sporulation, $\delta$ endotoxin synthesis and toxicity of Bacillus thuringiensis H14. World J. Microbiol. Biotechnol. 22, 305-310.

Setlow, P., 1994. Mechanisms which contribute to the long-term survival of spores of Bacillus species. Appl. Bacteriol. 76, S49-S60.

Setlow, B., Loshon, C.A., Genest, P.C., Cowan, A.E., Setlow, C., Setlow, P., 2002. Mechanisms of killing spores of Bacillus subtilis by acid, alkali and ethanol. J. Appl. Microbiol. 92, 362-375.

Setlow, P., 2003. Spore germination. Curr. Opin. Microbiol. 6, 550-556.

Setlow, P., 2006. Spores of Bacillus subtilis: their resistance to and killing by radiation, heat and chemicals. J. Appl. Microbiol. 101, 514-525.

Setlow, P., Johnson, E.A., 2007. Spores and their significance. In: Doyle, M.P., Beuchat, L.R. (Eds.), Food Microbiol. Fundamentals and Frontiers. ASM Press, Washington DC, pp. 35-68.

Severson, K.M., Mallozzi, M., Bozue, J., Welkos, S.L., Cote, C.K., Knight, K.L., Driks, A., 2009. Roles of the Bacillus anthracis spore protein ExsK in exosporium maturation and germination. J. Bacteriol. 191, 7587-7596.

Tam, N.K.M., Uyen, N.Q., Hong, H.A., Duc, L.H., Hoa, T.T., Serra, C.R., Henriques, A.O., Cutting, S.M., 2006. The intestinal life cycle of Bacillus subtilis and close relatives. J. Bacteriol. 188, 2692-2700.

van der Voort, M., Garcia, D., Moezelaar, R., Abee, T., 2010. Germinant receptor diversity and germination responses of four strains of the Bacillus cereus group. Int. J. Food Microbiol. 139, 108-115.

van der Voort, M., Abee, T., 2013. Sporulation environment of emetic toxinproducing Bacillus cereus strains determines spore size, heat resistance and germination capacity. J. Appl. Microbiol. 114, 1201-1210.

Westphal, A.J., Price, P.B., Leighton, T.J., Wheeler, K.E., 2003. Kinetics of size changes of individual Bacillus thuringiensis spores in response to changes in relative humidity. Proc. Natl. Acad. Sci. U.S.A. 100, 3461-3466.

Young, S.B., Setlow, P., 2003. Mechanisms of killing of Bacillus subtilis spores by hypochlorite and chlorine dioxide. J. Appl. Microbiol. 95, 54-67. 